\title{
ANALISIS PERLAKUAN AKUNTANSI PEMBIAYAAN IJARAH BERMASALAH PADA PT. BANK SYARIAH “X” DI INDONESIA
}

\author{
Muhammad Yusuf \\ Accounting and Finance Department, Faculty of Economics and Communication, BINUS University \\ Jln. K. H. Syahdan No. 9, Palmerah, Jakarta Barat 11480 \\ yusuf_moch2002@yahoo.com
}

\begin{abstract}
Disbursement of funds by Islamic banks expected to get results have direct implications to the fund owner. If the investments made by the Islamic banks have payments that are not smooth and even jammed, can result in a small earned income and income received by the owner of the funds raised to be too small. All types of financing provided by banks to customers have experienced financing problems. Based on the information and data obtained, the most problematic financing for 2010 is the ijara financing, which underlies the preparation of this study. Research uses descriptive method of analysis. The research objective was to determine how the application of $P T$. Bank Syariah " $X$ " in ijara financing problems, how it compares ijara financing problems in $P T$ Bank Syariah " $X$ " with non-performing loans at conventional banks, and how it compares to compliance with SFAS 107 on accounting ijara at PT. Bank Syariah " $X$ ". The benefits of research for the PT Bank Syariah " $X$ " can be an evaluation of the practice that has been done in Indonesia Islamic banking world. Bank Syariah " $X$ ". Accounting records ijara financing for the financing of the reverse problem of scheduling has been agreed will be recorded as revenue ijara receivables. The conclusion of the study is the recording of the restructured ijara financing, PT Bank Syariah " $X$ " will record the repayment of the existing contract and replace with a new contract that has been adjusted in both the number and schedule of installment payments previously agreed by the customer and the PT. Bank Syariah " $X$ ". Ijarah accounting records adopted by the PT Bank Syariah " $X$ " are in accordance with SFAS 107 on accounting ijara.
\end{abstract}

Keywords: Bank Syariah”X”, ijarah, ijarah muntahiyah bit tamlik

\begin{abstract}
ABSTRAK
Penyaluran dana yang dilakukan oleh bank syariah yang diharapkan mendapatkan hasil, mempunyai implikasi langsung ke pemilik dana. Jika investasi yang dilakukan oleh bank syariah mengalami pembayaran yang tidak lancar bahkan sampai macet, dapat mengakibatkan pendapatan yang diperoleh kecil dan pendapatan yang diterima oleh pemilik dana yang dihimpun menjadi kecil pula. Seluruh jenis pembiayaan yang diberikan oleh bank kepada nasabah pernah mengalami pembiayaan bermasalah. Berdasarkan informasi dan data yang diperoleh, pembiayaan bermasalah yang paling banyak untuk tahun 2010 adalah pembiayaan ijarah, hal ini yang mendasari penyusunan penelitian ini. Penelitian menggunakan metode deskriptif analisis. Tujuan penelitian adalah untuk mengetahui bagaimana penerapan PT. Bank Syariah " $X$ " dalam pembiayaan ijarah bermasalah, bagaimana perbandingan pembiayaan ijarah bermasalah pada PT Bank Syariah " $X$ ” dengan kredit bermasalah pada bank konvensional, dan bagaimana perbandingan kesesuaian dengan PSAK 107 tentang akuntansi ijarah pada PT. Bank Syariah " $X$ ". Manfaat penelitian untuk PT Bank Syariah " $X$ "dapat menjadi evaluasi mengenai praktek yang telah dilakukan di dunia perbankan syariah Indonesia. Kesimpulan dari penelitian adalah pencatatan pembiayaan ijarah yang direstrukturisasi, $P T$ Bank Syariah " $X$ "akan mencatat pelunasan akad yang ada dan mengganti dengan akad baru yang telah di sesuaikan baik dalam jumlah angsuran maupun jadwal pembayaran yang sebelumnya telah disepakati oleh nasabah dan PT. Bank Syariah " $X$ ". Pencatatan akuntansi pembiayaan ijarah bermasalah untuk pembiayaan yang mundur dari penjadwalan yang telah disepakati, akan di catat sebagai piutang pendapatan ijarah. Pencatatan akuntansi ijarah yang dilakukan oleh PT Bank Syariah "X”"telah sesuai dengan PSAK 107 tentang akuntansi ijarah.
\end{abstract}

Kata kunci: Bank Syariah”X”, ijarah, ijarah muntahiyah bit tamlik 


\section{PENDAHULUAN}

Salah satu fungsi bank syariah yang sangat penting adalah sebagai manajer investasi, karena bank syariah tersebut merupakan manajer investasi pemilik dana yang dihimpun. Hal ini disebabkan besar kecilnya pendapatan (bagi hasil) yang diterima oleh pemilik dana yang dihimpun sangat tergantung pada keahlian, kehati-hatian, dan profesionalisme dari bank syariah. Menurut Yusuf (2011) apabila selama ini fungsi bank konvensional dikenal sebagai intermediary (penghubung) antara pihak yang kelebihan dana dan membutuhkan dana selain menjalankan fungsi jasa keuangan, bank syariah mempunyai fungsi lain yang berbeda dengan bank konvensional, yaitu sebagai manajer investasi, investor, jasa keuangan, dan fungsi sosial.

Penyaluran dana yang dilakukan oleh bank syariah yang diharapkan mendapatkan hasil, mempunyai implikasi langsung ke pemilik dana. Jika investasi yang dilakukan oleh bank syariah mengalami pembayaran yang tidak lancar bahkan sampai macet, dapat mengakibatkan pendapatan yang diperoleh kecil. Setiap bank memiliki risiko. Risiko yang dihadapi bank syariah lebih terfokus pada risiko likuiditas dan risiko kredit. Risiko kredit yang dialami adalah kredit macet. Risiko-risiko ini harus diantisipasi agar pengaruh negatifnya terhadap perkreditan dapat diminimalkan. Kredit macet tidak akan terjadi jika tahap-tahap dalam proses pemberian kredit diikuti dengan baik. Bila suatu bank telah melakukan pemantauan dengan baik, berarti bank tersebut telah menjalankan early warning system, saat deteksi dini dilakukan untuk mengetahui indikasi-indikasi (signs) yang merupakan potential risk bagi perkreditan bank.

Menurut Suhardjono (2003), faktor-faktor penyebab kredit bermasalah disebabkan dari sisi debitur, sisi bank maupun debitur eksternal dan bank. Sisi debitur memiliki kelemahan pada faktor keuangan, faktor manajemen, dan faktor operasional. Sisi bank disebabkan kelemahan sejak awal dalam proses pemberian kredit, itikad tidak baik dan atau kekurangmampuan dari pegawai atau pejabat bank, serta kelemahan dalam pembinaan dan pengawasan kredit. Dari sisi debitur eksternal dan bank, kelemahan disebabkan force majeure, perubahan-perubahan lingkungan eksternal, perubahan peraturan pemerintah.

Berdasarkan penelitian sebelumnya oleh Haris (2007), keberagaman serta perbedaan skim fiqh dalam pembiayaan pemilikan rumah (KPR) oleh bank-bank syariah di Indonesia memiliki nilai negatif dan positif. Nilai negatifnya adalah memunculkan kesan bahwa tidak ada suatu otoritas khusus menangani operasional perbankan syariah di Indonesia sehingga muncul berbagai variasi produk pembiayaan kepemilikan rumah. Pembiayaan kepemilikan rumah ini, di bank syariah yang satu dengan bank syariah yang lain berbeda. Namun sebenarnya, di Indonesia sudah ada sebuah lembaga di bawah naungan MUI, yaitu Dewan syariah Nasional yang merumuskan aplikasi skim kontrak dalam bidang Hukum Islam ke dalam praktik lembaga-lembaga keuangan syariah, semisal bank. Segi positifnya adalah dengan berbagai macam variasi pembiayaan kepemilikan rumah yang ditawarkan oleh bank-bank syariah berarti calon nasabah mempunyai berbagai alternatif pemilihan untuk memiliki rumah dengan cara yang sesuai dengan keinginannya.

Kemudian pada penelitian berikutnya, Dewi (2009) menggunakan metode anuitas dalam menghitung jumlah angsuran yang harus dibayar. Pendapatan diakui berdasarkan metode kas basis. Beban penyusutan, pemeliharaan, beban akad ijarah diakui berdasarkan metode akrual. Biaya penyusutan menggunakan metode garis lurus, metode pencatatan sudah sesuai dengan PSAK No.107.

Dan penelitian oleh Hijrianto (2010), dapat disimpulkan bahwa ijarah adalah salah satu prinsip syariah yang digunakan untuk memberikan pembiayaan berdasarkan prinsip syariah oleh bank syariah menurut UU no.10/1998 tentang perbankan dan undang-undang no. 21 tahun 2008 tentang perbankan syariah. Pada tahun 2007 yang menarik adalah pertumbuhan pembiayaan diikuti dengan 
peningkatan dukungan kepada sektor riil dengan rasio FDR 104\% namun dengan rasio pembiayaan bermasalah (NPF) yang masih terjaga di level 3,8\%. Sementara itu, penyaluran pembiayaan mengalami peningkatan sebesar 22\% menjadi Rp10,48 triliun dengan rasio pembiayaan atas simpanan sebesar 104\%, dan pembiayaan bermasalah (NPF) sebesar 3,8\% pada 2008. Perolehan (NPF) Nett yang pada 2009 sebesar 4,10\% dan menurun menjadi 3,51\% pada 2010. Sebagian besar pembiayaan bermasalah berasal dari pembiayaan dengan akad ijarah muntahiya bit tamlik.

Berdasarkan latar belakang di atas, maka judul penulisan penelitian ini adalah "Analisis Perlakuan Akuntansi Pembiayaan Ijarah Bermasalah pada PT. Bank Syariah “X” di Indonesia”.

\section{METODE PENELITIAN}

Penelitian ini sendiri merupakan penelitian yang dilakukan dengan kegiatan mengumpulkan berbagai data primer yang diperoleh dari sumber pertama. Adapun yang dilakukan adalah sebagai berikut.

\section{Metode Pengumpulan Data}

Data primer, merupakan data yang diperoleh dari sumber pertama. Untuk mengumpulkan data primer tersebut dapat dilakukan dengan cara: observasi (observation), wawancara (interview) yaitu melakukan wawancara dengan pihak terkait finance and strategy division mengenai perlakuan akuntansi pembiayaan ijarah bermasalah.

Data sekunder, merupakan data yang telah dipublikasikan baik berupa laporan keuangan, artikel-artikel yang berkaitan dengan riset ini melalui studi Pustaka (Library Research). Studi pustaka dilakukan dari buku-buku, yaitu Bank Syariah Dari Teori Ke Praktik, Bisnis Syariah, Manajemen Perbankan, Melacak Kredit Bermasalah, Akuntansi Syariah di Indonesia, Credit and Management Handbook, Bank And Financial Institution Management, Islamic Financial Management, Islamic Banking, Dan Lembaga Keuangan Lain, Akuntansi Perbankan Syariah, Bisnis Syariah, jurnal yang berkaitan dengan judul penulisan ini, laporan kolektabilitas PT. Bank Syariah "X", maupun artikel yang mendukung judul penulisan ini.

\section{Metode Analisis Data}

Dalam penelitian ini, metode analisis data yang digunakan termasuk dalam penelitian deskriptif. Riset ini bertujuan untuk menggambarkan atau mendefiniskan yang terlibat dalam suatu kegiatan, yang dilakukannya, tempat dan cara melakukannya.

\section{HASIL DAN PEMBAHASAN}

Pembiayaan ijarah yang pernah bermasalah pada PT. Bank Syariah "X” Indonesia adalah pembiayaan dengan akad Ijarah Muntahiya Bit Tamlik (IMBT). Penyebab pembiayaan ijarah bermasalah pada PT. Bank Syariah "X" Indonesia, di antaranya adalah nasabah mengalami kesulitan atau penurunan dalam usahanya, kelalaian dalam monitoring atau kesalahan dalam tahap evaluasi. Penyebab lainnya karena ada situasi yang di luar perencanaan awal pembiayaan yang tidak sesuai dengan perencanaan awal nasabah dan Bank Syariah " $X$ " Indonesia yang pada akhirnya dapat menyebabkan turunnya kemampuan bayar nasabah, seperti: kendala dari pihak PLN yang tidak dapat mengalirkan listrik ke semua tempat produksi nasabah. 
Jika terjadi pembiayaan bermasalah, Bank Syariah “X” Indonesia akan menghubungi nasabah terkait untuk melakukan musyawarah guna mencari jalan keluar, dengan cara melakukan restrukturisasi pembiayaan. Restrukturisasi pembiayaan adalah upaya perbaikan yang dilakukan bank dalam kegiatan pembiayaan terhadap nasabah yang mengalami kesulitan untuk memenuhi kewajibannya. Restukturisasi dapat dilakukan melalui beberapa cara, yaitu: Penjadwalan kembali, yaitu perubahan jadwal pembayaran kewajiban nasabah atau jangka waktu; Persyaratan kembali, yaitu perubahan sebagian atau seluruh persyaratan pembiayaan yang tidak terbatas pada perubahan jadwal pembayaran, jangka waktu, dan atau persyaratan lainnya sepanjang tidak menyangkut perubahan maksimum plafon pembiayaan; Penataan kembali, yaitu perubahan persyaratan pembiayaan yang menyangkut penambahan fasilitas pembiayaan dan konversi seluruh atau sebagian tunggakan angsuran biaya sewa menjadi pokok pembiayaan baru yang dapat disertakan dengan penjadwalan kembali dan atau persyaratan kembali.

Langkah yang biasa diambil oleh Bank Syariah “ $X$ ” Indonesia untuk mengatasi pembiayaan bermasalah adalah dengan memberikan perpanjangan jangka waktu pembiayaan dengan harapan pembiayaan akan kembali normal. Apabila setelah diberikan perpanjangan jangka waktu pembayaran ternyata pembiayaan tersebut masih bermasalah, Bank Syariah "X" akan menawarkan langkah berikutnya yaitu persyaratan kembali yang mencakup perubahan jadwal pembayaran dan jumlah pembayaran setelah diadakannya kesepakatan ulang antara nasabah dengan Bank Syariah " $X$ " Indonesia. Jika persyaratan kembali belum berhasil, bank akan melakukan penataan kembali, menyangkut jumlah pembayaran yang sebelumnya berserta margin untuk bank, akan dibuatkan penjadwalan ulang untuk pembayaran pokok pembiayaan saja, tanpa margin untuk bank. Dalam proses ini PT. Bank Syariah "X" Indonesia juga memungkinkan untuk menyarankan kepada nasabah untuk melakukan pergantian akad yang sekiranya dapat memudahkan nasabah untuk melunasi kewajibannya. Pencatatan yang dilakukan Bank Syariah "X" Indonesia pada saat nasabah dan bank sepakat untuk mengganti akad ijarah menjadi akad lain adalah Bank Syariah "X" Indonesia akan mencatat pelunasan akad yang ada (ijarah), kemudian mencatat pelaksanaan akad yang baru.

Apabila setelah opsi-opsi tersebut diberikan nasabah masih tidak mampu untuk melanjutkan akad ijarah, Bank Syariah "X" akan melakukan penyitaan aset jaminan yang selanjutnya akan dilelang atau dijual untuk melunasi sisa pembiayaan yang belum dilunasi. Jika nasabah beritikad tidak baik dengan cara menghindar atau melarikan diri, Bank Syariah " $X$ " akan melakukan penyelesaian melalui jalan hukum dengan mengajukan tuntutan ke pengadilan negeri.

Bank Syariah " $X$ " Indonesia menerapkan sistem denda apabila terjadi keterlambatan pembayaran oleh nasabah. Namun, apabila nasabah membayar sebelum 14 hari setelah tanggal jatuh tempo angsuran, uang denda tersebut dikembalikan ke nasabah. Jika melebihi 14 hari setelah tanggal jatuh tempo angsuran, denda tersebut akan disalurkan ke Baitul Maal Muamalat sebagai dana nonhalal. Tujuan sistem denda diterapkan adalah sebagai upaya mendisiplinkan nasabah dalam memenuhi kewajibannya membayar angsuran tepat pada waktunya. Dan Bank Syariah "X" Indonesia tidak pernah menyisihkan dana untuk pembiayaan bermasalah. Pembiayaan bermasalah pada Bank Syariah "X” Indonesia dapat digolongkan mulai dari koll 3 atau disebut juga kurang lancar dan berapa pun plafonnya sudah dikategorikan Non Performing Financing (NPF).

\section{Perbandingan Kesesuaian dengan PSAK 107 tentang Akuntansi Ijarah pada PT. Bank Syariah “ $X$ ” Indonesia, Tbk.}

Pedoman yang digunakan oleh Bank Syariah "X” Indonesia untuk pencatatan akuntansi ijarah adalah PSAK 107. Apabila terjadi pembiayaan ijarah bermasalah pada Bank Syariah " $X$ " Indonesia, perlakuan akuntansinya yang perlu dilakukan adalah melakukan pelunasan terlebih dahulu pembiayaan yang ada (pembiayaan ijarah yang bermasalah), selanjutnya dibuat pembiayaan baru dengan pola atau metode kesepakatan baru, yang disertai akad baru notaris. Contoh kasus: 
PT. BFB yang bergerak di bidang rental peralatan berat mengajukan permohonan pembiayaan ijarah muntanhiyah bit tamlik kepada Bank Syariah "X" Indonesia untuk pembelian dan instalasi GE Jenbacher Gas Engine yaitu sebuah mesin genset berbahan bakar gas dengan fasilitas pembiayaan sebesar US\$1.323.251. Seperti yang dijelaskan pada Fatwa Dewan Syariah Nasional No. 27/DSNMUI/III/2002, bahwa pihak-pihak yang melakukan ijarah muntanhiyah bit tamlik harus melaksanakan akad ijarah terlebih dahulu. Maka, PT. BFB selaku pihak yang ingin menggunakan fasilitas ijarah muntanhiyah bit tamlik harus terlebih dahulu melaksanakan akad ijarah dengan bank. Setelah permohonan pembiayaan diterima, Bank Syariah "X" Indonesia melalui account officer-nya akan menganalisis permohonan pembiayaan yang diajukan oleh PT. BFB, selanjutnya account officer mempresentasikan hasil analisisnya kepada komite pembiayaan untuk memperoleh persetujuan pembiayaan. Setelah permohonan pembiayaan PT. BFB disetujui, lebih lanjut Bank Syariah "X" Indonesia akan menentukan jumlah angsuran yang akan dibebankan kepada PT. BFB sebagai tarif sewa melalui margin yang telah ditetapkan oleh Bank Syariah "X" Indonesia, dengan rincian sebagai berikut: (a) Harga beli barang dari supplier (PT. Showa) sebesar US\$1.323.251 dengan margin sebesar US\$334.010, sehingga harga jual mesin genset tersebut sebesar US\$ 1.657.261; (b) Margin Bank Syariah " $X$ " Indonesia setara 11\% pa; (c) Angka waktu fasilitas 48 bulan dengan grace period 4 bulan; (d) Opsi perpindahan kepemilikan dengan penjualan sebesar harga sisa cicilan sewa.

\section{Perhitungan Margin Ijarah}

Jumlah angsuran (lihat formula jumlah angsuran):

$$
\begin{aligned}
A T & =1.323 .251 \times \frac{0,0091}{1-\frac{1}{(1+0.0091)^{44}}} \\
& =36.680
\end{aligned}
$$

karena ada grace period selama 4 bulan, jadi $n$ yang dipakai hanya 44 bulan yaitu setelah grace period selesai. Sehingga, jumlah angsuran / tariff sewa yang dibebankan kepada PT. BFB adalah \$ 36.680.

Jumlah porsi margin ( lihat formula porsi margin):

$$
\mathrm{AM}_{1}=1.323 .351 \times 0.11 / 12=12.130
$$

Jadi, jumlah porsi margin yang pertama kali harus dibayar oleh PT. BFB adalah \$12.130.

Jumlah porsi pokok (lihat formula porsi pokok):

$$
\mathrm{AP}_{5}=36.680-12.130=24.550
$$

Jadi, jumlah porsi pokok yang ke-5 yang harus dibayar oleh PT. BFB adalah \$24.550.

\section{Pencatatan Ayat Jurnal Transaksi Ijarah}

Berikut pencatatan transaksi-transaksi yang terjadi selama masa akad ijarah berlangsung, yaitu: pertama, pada saat pembelian barang oleh bank dari supplier, pada 14 September 2006 Bank Syariah " $X$ " Indonesia membeli mesin genset dengan harga perolehan sebesar US\$1,323,251 dari supplier (PT. Showa) dengan kurs Rupiah Rp.9.123.

Menurut PSAK 107 tentang ijarah, pencatatan untuk pembelian aktiva ijarah adalah:

Dr. Aset ijarah

Cr. Kas/rekening pemilik aset $\mathrm{xxx}$

$\mathrm{XXX}$ 
ialah:

Pencatatan yang dilakukan oleh Bank Syariah “X” Indonesia untuk pembelian aktiva ijarah,

Dr. Persediaan/aset ijarah

Cr. Rekening PT. Showa
US\$1.323.251

US\$1.323.251

Berdasarkan hasil analisis antara PSAK 107 dengan pencatatan yang dilakukan oleh Bank Syariah "X" Indonesia atas transaksi pembelian aset ijarah dari PT. Showa selaku supplier telah sesuai dengan PSAK 107.

Kedua, pada saat pelaksanaan akad ijarah (transaksi ijarah antara Bank Syariah "X” Indonesia dengan PT. BFB), pada saat perjanjian ijarah dilaksanakan, maka bank sebagai pemilik objek sewa akan mencatat aktiva yang diperoleh untuk ijarah didebet, karena kepemilikan objek sewa masih ada di Bank Syariah "X” Indonesia, serta mencatat persediaan ijarah dikredit. adalah:

Menurut PSAK 107 tentang ijarah, pencatatan pada saat pelaksanaan akad ijarah dilakukan

Dr. Aktiva yang diperoleh untuk ijarah

Cr. Persediaan ijarah

$\mathrm{xxx}$

Pencatatan yang dilakukan Bank Syariah "X” Indonesia pada saat pelaksanaan akad ijarah dilakukan, adalah:

Dr. Aktiva yang diperoleh untuk ijarah

US\$1.323.251

Cr. Persediaan ijarah

US\$1.323.251

Berdasarkan hasil analisis antara PSAK 107 dengan pencatatan yang dilakukan oleh Bank Syariah "X" Indonesia pada saat pelaksanaan akad ijarah dilakukan telah sesuai dengan PSAK 107.

\section{Pada Saat Bank Menerima atau Mengakui Pendapatan Sewa dari PT. BFB}

Bank Syariah “X” Indonesia sepakat dengan PT. BFB bahwa uang sewa yang didapatkan bank tiap bulannya ialah US\$36.680 (lihat tabel angsuran), kecuali pada saat grace period untuk 4 bulan pertama bank hanya membayar sebesar porsi marginnya saja yaitu US\$12.130.

Menurut PSAK 107 tentang ijarah, pencatatan pada saat grace period, adalah:

Dr. Kas/rekening penyewa

XXX

Cr. Pendapatan Sewa

$\mathrm{xxx}$

Pencatatan yang dilakukan Bank Syariah “X” Indonesia pada saat grace period, yaitu:

Dr. Rekening PT. BFB

US\$ 12.130

Cr. Pendapatan Ijarah

US\$ 12.130

Berdasarkan hasil analisis antara PSAK 107 dengan pencatatan yang dilakukan oleh Bank Syariah "X" Indonesia pada saat grace period telah sesuai dengan PSAK 107.

Pencatatan tersebut berlaku selama grace period, yaitu pada bulan Oktober, November, dan Januari. Untuk bulan Desember, Bank tidak mencatat seperti di atas karena pada bulan Desember Bank tidak menerima pembayaran uang sewa dari PT. BFB karena PT. BFB belum membayar sewa untuk bulan Desember. 
Menurut PSAK 107 tentang ijarah, pencatatan untuk mengakui pendapatan ijarah pada saat grace period telah selesai, yaitu:

Dr. Kas/rekening penyewa

$\mathrm{xxx}$

Cr. Pendapatan Sewa

$\mathrm{xxx}$

Pencatatan yang dilakukan Bank Syariah "X” Indonesia untuk mengakui pendapatan ijarah pada saat grace period telah selesai, yaitu:

Dr. Rekening PT. BFB

US\$36.680

Cr. Pendapatan Ijarah

US\$36.680

Jumlah pendapatan ijarah sebesar US\$36.680 merupakan penjumlahan dari porsi pokok dan porsi margin.

Berdasarkan hasil analisis antara PSAK 107 dengan pencatatan yang dilakukan oleh Bank Syariah "X" Indonesia pada saat grace period telah selesai, telah sesuai dengan PSAK 107.

\section{Pada Saat Jatuh Tempo Pembayaran Sewa}

Bank Syariah "X" Indonesia mengakui pembayaran sewa yang telah jatuh tempo sebagai piutang ijarah. Pada saat angsuran sewa yang ketiga jatuh tempo pada 19 Desember 2006 dengan kurs Rupiah sebesar Rp.9.156 yaitu sebesar US\$12.130 (lihat tabel angsuran), PT. BFB belum melakukan pembayaran, sehingga Bank Syariah "X” Indonesia mengakui adanya piutang pendapatan ijarah pada tanggal tersebut.

Menurut PSAK 107 tentang ijarah, pencatatan untuk mengakui angsuran sewa yang telah jatuh tempo, yaitu:

Dr. Piutang Pendapatan Ijarah

$\mathrm{xxx}$

Cr. Pendapatan Ijarah

$\mathrm{XXX}$

Pencatatan yang dilakukan oleh Bank Syariah " $X$ ” Indonesia untuk mengakui angsuran sewa ke-3 yang telah jatuh tempo, ialah:

Dr. Piutang Pendapatan Ijarah

US\$ 12.130

Cr. Pendapatan Ijarah

US\$ 12.130

Berdasarkan hasil analisis antara PSAK 107 dengan pencatatan yang dilakukan oleh Bank Syariah "X" Indonesia pada saat mengakui angsuran sewa yang telah jatuh tempo, telah sesuai dengan PSAK 107.

\section{Pada Saat Bank Mengakui Pendapatan dari Biaya Administrasi}

Pada saat akad ijarah dilaksanakan yaitu tanggal 18 September 2006, ada biaya administrasi yang harus dibayar oleh PT. BFB yaitu sebesar US\$500 dengan kurs Rupiah pada saat itu sebesar Rp.9.138 dan bank akan mencatatnya sebagai pendapatan fee ijarah.

Menurut PSAK 107 tentang ijarah, pencatatan untuk mengakui pendapatan dari biaya administrasi, yaitu:

Dr. Kas/rekening penyewa

$\mathrm{xxx}$

Cr. Pendapatan fee ijarah

$\operatorname{XXX}$ 
Pencatatan yang dilakukan oleh Bank Syariah “X” Indonesia untuk mengakui pendapatan dari biaya administrasi, adalah:

$$
\begin{aligned}
& \text { Dr. Rekening PT. BFB } \\
& \text { Cr. Pendapatan fee ijarah }
\end{aligned}
$$

\section{US\$500}

Pencatatan yang dilakukan oleh Bank Syariah "X” Indonesia langsung dengan menggunakan mata uang asing, karena Bank baru akan melakukan pengkonversian ke rupiah pada saat akhir periode. Berdasarkan hasil analisis antara PSAK 107 dengan pencatatan yang dilakukan oleh Bank Syariah "X" Indonesia pada saat mengakui pendapatan dari biaya administrasi, telah sesuai dengan PSAK 107.

\section{Pada Saat Mengakui Adanya Biaya Perbaikan Rutin dan Biaya Pemeliharaan}

Secara prinsip aset ijarah adalah milik Bank Syariah "X” Indonesia, sehingga biaya perbaikan rutin dan pemeliharaan atas aktiva ijarah tersebut menjadi tanggung jawab Bank Syariah " $\mathrm{X}$ " Indonesia dan diakui pada saat terjadinya. Akan tetapi, jika biaya perbaikan rutin dan pemeliharaan itu terjadi karena kelalaian atau kesalahan musta'jir, Bank Syariah "X" Indonesia akan melakukan penelitian terlebih dahulu terhadap biaya perbaikan rutin dan pemeliharaan yang nantinya akan dibebankan kepada bank. Pada 12 Maret 2007 PT. BFB memberikan informasi kepada Bank Syariah “X” Indonesia bahwa ada biaya pemeliharaan aktiva ijarah sebesar US\$925 dengan kurs Rupiah pada saat itu sebesar Rp.9.165.

Menurut PSAK 107 tentang ijarah, pencatatan untuk mengakui biaya perbaikan rutin dan pemeliharaan, yaitu:

$$
\begin{aligned}
& \text { Dr. Biaya perbaikan aktiva ijarah } \\
& \text { Cr. Kas }
\end{aligned}
$$

$\mathrm{xxx}$

$$
\mathrm{xxx}
$$

Pencatatan yang dilakukan oleh Bank Syariah "X” Indonesia untuk mengakui biaya perbaikan rutin dan pemeliharaan, adalah:

$$
\begin{aligned}
& \text { Dr. Beban perbaikan aktiva ijarah } \\
& \text { Cr. Kas }
\end{aligned}
$$

Untuk biaya perbaikan rutin dan biaya pemeliharaan aktiva ijarah jumlahnya selalu berubah-ubah tidak pernah sama.

Berdasarkan hasil analisis antara PSAK 107 dengan pencatatan yang dilakukan oleh Bank Syariah " $X$ " Indonesia pada saat mengakui biaya perbaikan rutin dan pemeliharaan, telah sesuai dengan PSAK 107.

\section{Pencatatan Ayat Jurnal Transaksi Ijarah Muntanhiyah Bit Tamlik}

Pada saat pengakuan penyusutan aktiva ijarah oleh Bank Syariah "X" Indonesia, saat awal akad, permohonan fasilitas pembiayaan yang diajukan oleh PT. BFB adalah fasilitas pembiayaan ijarah muntanhiyah bit tamlik. Oleh karena itu, ketentuan penyusutan yang berlaku pada Bank Syariah "X" Indonesia yaitu sesuai dengan masa sewa, jadi besarnya penyusutan aktiva ijarah tergantung lama masa sewanya. Sesuai dengan contoh kasus di atas, nilai sisa dari aktiva ijarah diperkirakan oleh Bank Syariah "X” Indonesia sebesar 20\% dan masa sewa diketahui selama 4 tahun.

Menurut PSAK 107 tentang ijarah, penyusutan aktiva ijarah per bulannya, yaitu sebagai berikut. 


$$
=\frac{(\text { harga perolehan }- \text { nilai residu })}{\text { Jangka waktu penyusutan/sewa }}
$$

Perhitungan yang dilakukan oleh Bank Syariah " $X$ ” Indonesia untuk penyusutan aktiva ijarah perbulannya, adalah sebagai berikut.

$$
\begin{aligned}
& =\frac{\text { Harga Perolehan }-(20 \% \text { X Harga Perolehan })}{4} \\
& =\frac{1.323 .251-(20 \% \times 1.323 .251)}{4} \\
& =\$ 264.650 \text { (penyusutan pertahun) }
\end{aligned}
$$

Jadi, penyusutan tiap bulannya pada akhir pelaporan, adalah sebagai berikut.

$$
\begin{aligned}
& =\frac{1}{12} * 264.650 \\
& =\$ 22.054 \text { (penyusutan perbulan) }
\end{aligned}
$$

Menurut PSAK 107 tentang ijarah, pencatatan untuk mengakui penyusutan aktiva ijarah tiap bulannya pada akhir pelaporan, yaitu:

Dr. Beban penyusutan aktiva ijarah

$\mathrm{XXX}$

Cr. Akumulasi penyusutan aktiva ijarah

$\operatorname{XXX}$

Pencatatan yang dilakukan oleh Bank Syariah "X” Indonesia untuk mengakui penyusutan aktiva ijarah tiap bulannya pada akhir pelaporan, ialah:

Dr. Beban penyusutan aktiva ijarah

US\$22.054

Cr. Akumulasi penyusutan aktiva ijarah

US\$ 22.054

Berdasarkan hasil analisis antara PSAK 107 dengan pencatatan yang dilakukan oleh Bank Syariah "X" Indonesia pada saat mengakui beban penyusutan aktiva ijarah, telah sesuai dengan PSAK 107.

Pada saat perpindahan hak milik objek sewa melalui penjualan objek sewa dengan harga sebesar sisa cicilan, awal akad, PT. BFB mempunyai hak opsi perpindahan kepemilikan melalui penjualan objek sewa dengan harga sebesar sisa cicilan sebelum berakhirnya masa sewa dan Bank Syariah " $X$ " Indonesia nantinya akan mengakui keuntungan atau kerugian atas penjualan tersebut sebesar selisih antara harga jual dan nilai buku bersih objek sewa. Sesuai dengan contoh kasus di atas bahwa masa ijarah selesai pada 19 September 2010, dengan menggunakan asumsi bahwa pada 19 Maret 2010, PT. BFB menggunakan hak opsinya untuk membeli objek sewa sebesar sisa sewa yaitu 7 bulan sewa sebesar US\$220.101 (lihat jadwal angsuran). Dan besarnya penyusutan sampai tanggal 19 Februari 2010 adalah US\$904.214 ( 41 bulan x 22.054 ).

Menurut PSAK 107 tentang ijarah, pencatatan pada saat perpindahan hak milik objek sewa melalui penjualan objek sewa dengan harga sebesar sisa cicilan, yaitu:

Dr. Kas/rekening penyewa

Dr. Akumulasi penyusutan aktiva ijarah

Dr. Kerugian penjualan aktiva ijarah

Cr. Aktiva ijarah
XXX

XXX

XXX
XXX 
Pencatatan yang dilakukan Bank Syariah "X” Indonesia pada saat perpindahan hak milik objek sewa melalui penjualan objek sewa dengan harga sebesar sisa cicilan, adalah sebagai berikut.
Dr. Kas
Dr. Akumulasi penyusutan aktiva ijarah
Dr. Kerugian penjualan aktiva ijarah
Cr. Aktiva yang diperoleh untuk ijarah

US\$ 220.101

US\$ 904.214

US\$ 198.936

Jika PT. BFB menggunakan hak opsinya untuk membeli objek sewa sebesar sisa sewa, membuat Bank Syariah “X” Indonesia mengalami kerugian sebesar US\$198.936.

Berdasarkan hasil analisis antara PSAK 107 dengan pencatatan yang dilakukan oleh Bank Syariah "X" Indonesia pada saat perpindahan hak milik objek sewa melalui penjualan objek sewa dengan harga sebesar sisa cicilan, telah sesuai dengan PSAK 107.

Pada saat pembiayaan bermasalah, pembiayaan mulai bermasalah pada bulan ke-41. PT. BFB dan Bank Syariah " $X$ ” Indonesia sepakat sisa pembiayaan yang belum dibayarkan oleh PT.BFB akan diganti menjadi akad murabahah dengan biaya administrasi sebesar Rp.1.000.000. Berikut pencatatan yang dilakukan oleh Bank Syariah "X”. berikut:

Bank Syariah “X” Indonesia akan mencatat pelunasan pembiayaan yang ada (ijarah) sebagai

Dr. Kas

Dr. Akumulasi penyusutan aktiva ijarah

Dr. Kerugian penjualan aktiva ijarah

Cr. Aktiva yang diperoleh untuk ijarah
US\$ 220.101

US\$ 904.214

US\$ 198.936

US\$ 1.323.251

Pencatatan pengakuan pendapatan administrasi murabahah
Dr. Rekening PT. BFB
Cr. Pendapatan fee murabahah

Rp. 1.000 .000

Rp. 1.000 .000

\section{Penyajian}

Menurut PSAK 107 tentang akuntansi ijarah, penyajian ijarah disajikan secara netto setelah dikurangi beban yang terkait, misalnya beban penyusutan, beban pemeliharaan dan perbaikan, dan sebagainya. Penyajian pembiayaan ijarah dan ijarah muntanhiyah bit tamlik dalam neraca Bank Syariah " $X$ ” Indonesia sebagai berikut (berdasarkan dengan contoh kasus yang ada sampai dengan 31 Desember 2006).

Objek sewa yang dibeli Bank Syariah "X” Indonesia sebesar harga perolehan yang bertujuan untuk disewakan kembali disajikan dalam neraca pada pos aktiva yang diperoleh untuk ijarah. Berdasarkan contoh kasus yang ada, harga perolehan mesin genset sebesar US\$1.323.251 dengan kurs rupiah pada saat tanggal pembelian sebesar Rp.9.123. Jadi jumlah nilai aktiva yang diperoleh untuk ijarah (sebelum dikurangi akumulasi penyusutan) sebesar Rp.12.072.018.873.

Akumulasi penyusutan aktiva ijarah disajikan sebagi pos lawan dari aktiva ijarah. Berdasarkan dengan contoh kasus yang ada, Bank Syariah " $X$ ” Indonesia setiap bulannya mengakui adanya akumulasi penyusutan sebesar US\$22.054 dengan kurs rupiah pada saat tanggal pembelian sebesar Rp.9.123. Jadi jumlah nilai akumulasi penyusutan aktiva ijarah Bank Syariah "X” Indonesia sampai dengan 31 Desember 2006 adalah Rp.603.595.926. 
Pendapatan sewa yang sudah jatuh tempo, namun belum diperoleh Bank Syariah "X" Indonesia disajikan dalam neraca pada pos piutang pendapatan ijarah. Pada Desember 2006, PT. BFB belum membayar angsuran sewa kepada bank, sehingga untuk bulan Desember 2006, Bank mengakui piutang pendapatan ijarah dalam neraca Bank Syariah "X” Indonesia sebesar Rp.108.975.920 \{ Rp. 111.062.280 (kurs rupiah tanggal 19 Desember 2006 sebesar Rp. 9.156 x jumlah angsuran US\$ 12.130) + Rp. 2.086.360 (penyesuaian kurs Rupiah pada tanggal 31 Desember 2006)

Gambar 1 Neraca (kolom aktiva) Bank Syariah "X" per tanggal 31 Desember 2006 dan 31 Maret 2007 (dalam ribuan rupiah)

\begin{tabular}{|c|c|c|}
\hline Aktiva & 31 Desember 2006 & 31 Maret 2007 \\
\hline Kas & $\mathrm{xxx}$ & $\mathrm{xxx}$ \\
\hline Piutangpendapatanijarah & 108.975 .92 & 0 \\
\hline Aktiva yang diperoleh untuk ijarah & & \\
\hline Nilai tercatat & 12.072 .018 .87 & 12.072 .018 .87 \\
\hline Akumulasi penyusutan & $(603.595 .92)$ & $(1.207 .191 .85)$ \\
\hline Aktiva yang diperoleh untukijarah -bersih & 11.577 .398 .87 & 10.864 .827 .02 \\
\hline
\end{tabular}

(Sumber: Data olahan Bank Syariah “X”)

Nilai akumulasi penyusutan didapat dari penjumlahan akumulasi penyususutan untuk bulan Oktober sampai dengan bulan Desember dengan menggunakan kurs Rupiah pada saat tanggal pembelian sebesar Rp.9.123. Berdasarkan hasil analisis antara PSAK 107 dengan penyajian yang dilakukan oleh Bank Syariah "X” Indonesia, telah sesuai dengan PSAK 107.

Gambar 2 Laporan Laba Rugi Bank Syariah "X” per tanggal 31 Desember 2006 dan 31 Maret 2007 (dalam ribuan rupiah)

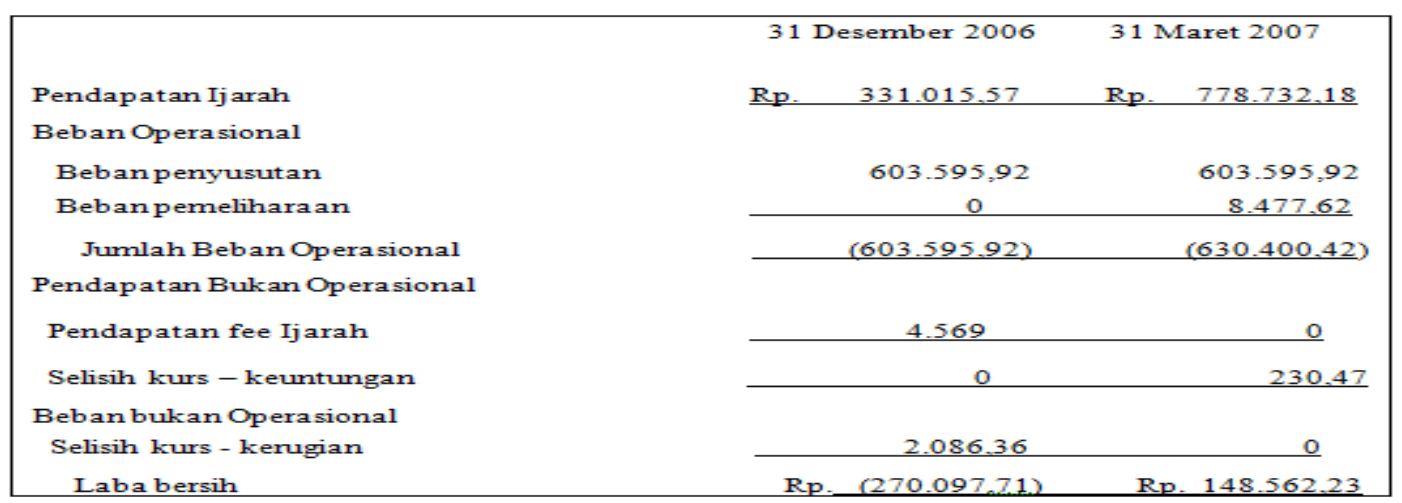

(Sumber: Data Olahan Bank Syariah “X”)

Jumlah pendapatan ijarah pada pelaporan tanggal 31 Desember 2006 didapat dari perhitungan dibawah ini :

Kurs Rupiah 19 oktober 2006 sebesar Rp. 9.158 x US\$ $12.130=$ Rp. 111.086 .540

Kurs Rupiah 19 November 2006 sebesar Rp. 9.147 x US\$ 12.130 = Rp. 110.953 .110

Kurs Rupiah 19 Desember 2006 sebesar Rp. 9.040 x US\$ $12.130=$ Rp. 111.062.280 
Beban penyusutan diakui tiap akhir bulan adalah sebesar Rp.201.198.642. Jumlah pendapatan ijarah pada pelaporan tanggal 31 Maret 2007 didapat dari perhitungan sebagai berikut.

Kurs Rupiah 19 Januari 2007 sebesar Rp. 9.070 x US\$ 12.130 = Rp. 110.019.100

Kurs Rupiah 19 Februari 2007 sebesar Rp. 9.070 x US\$ $36.680=$ Rp. 332.687 .600

Kurs Rupiah 19 Maret 2007 sebesar Rp. 9.161 x US\$ 36.680 = Rp. 336.025.480

\section{Pengungkapan}

Menurut PSAK 107 tentang akuntansi ijarah, pemilik mengungkapkan dalam laporan keuangan terkait transaksi ijarah dan ijarah muntahiyah bittamlik, tetapi tidak terbatas, pada: penjelasan umum isi akad yang signifikan yang meliputi, tetapi tidak terbatas pada, keberadaan wa'd pengalihan kepemilikan dan mekanisme yang digunakan (jika wa'd pengalihan kepemilikan), pembatasan-pembatasan, misalnya ijarah-lanjut, agunan yang digunakan (jika ada). Nilai perolehan dan akumulasi penyusutan atau amortisasi untuk setiap kelompok aset ijarah. Keberadaan transaksi jual dan ijarah (jika ada). Pengungkapan transaksi ijarah dan ijarah muntanhiyah bit tamlik pada Bank Syariah "X” Indonesia, mencakup: (a) kebijakan akuntansi yang digunakan atas transaksi ijarah dan ijarah muntanhiyah bit tamlik. (b) Kebijakan akuntansi yang ada di Bank Syariah "X” Indonesia mengatur mengenai penyusutan aktiva yang diperoleh untuk ijarah, dengan ketentuan sebagai berikut: 1) untuk transaksi ijarah, aktiva ijarah disusutkan dengan menggunakan straight line method. 2) Sedangkan untuk transaksi ijarah muntanhiyah bit tamlik, aktiva ijarah disusutkan sesuai dengan masa sewanya.

Berdasarkan hasil analisis, antara PSAK 107 dengan pengungkapan yang dilakukan oleh Bank Syariah “X” Indonesia telah sesuai dengan PSAK 107.

\section{SIMPULAN}

Berdasarkan hasil pembahasan data yang dilakukan terhadap PT Bank Syariah "X” Indonesia, maka dapat disimpulkan bahwa: pertama, pembiayaan bermasalah pada Bank Syariah " $X$ " Indonesia dapat digolongkan mulai dari coll 3 atau disebut juga kurang lancar dan berapapun plafonnya sudah dikategorikan Non Performing Financing (NPF). Penyebab pembiayaan ijarah bermasalah pada PT. Bank Syariah " $X$ " Indonesia, Tbk. adalah nasabah mengalami kesulitan atau penurunan dalam usahanya, kelalaian dalam monitoring atau kesalahan dalam tahap evaluasi. Jika terjadi pembiayaan bermasalah, Bank Syariah "X” Indonesia akan melakukan restrukturisasi pembiayaan atas kesepakatan dengan nasabah yang mencakup penjadwalan kembali, persyaratan kembali, penataan kembali. Apabila setelah opsi-opsi tersebut diberikan, tetapi nasabah masih tidak mampu untuk melanjutkan akad ijarah, Bank Syariah "X" akan melakukan penyitaan aset jaminan yang akan dilelang atau dijual untuk melunasi sisa pembiayaan yang belum dilunasi. Bank Syariah "X” Indonesia menerapkan sistem denda apabila terjadi keterlambatan pembayaran oleh nasabah sebagai upaya mendisiplinkan nasabah dalam memenuhi kewajibannya membayar angsuran tepat pada waktunya.

Kedua, terdapat perbedaan antara kredit (yang diberikan oleh bank konvensional), pembiayaan (yang diberikan oleh bank syariah) dengan leasing (yang diberikan oleh perusahaan pembiayaan). Kredit dan pembiayaan ijarah bertujuan menyediakan dana sementara leasing bertujuan menyewakan barang modal. Kredit terfokus kepada uang, jadi kreditur bukan pemilik dari barang yang didanai. Pembiayaan ijarah pada dasarnya mempunyai definisi yang sama dengan kredit, bedanya pada prinsip syariah yang digunakan. Perbedaan yang kedua adalah bank dapat memiliki atau tidak memiliki barang yang didanai. Sedangkan pada leasing, paling tidak secara yuridis, lessor merupakan pemilik barang modal. 
Ketiga, pencatatan akuntansi ijarah yang diterapkan oleh PT. Bank Syariah "X” Indonesia telah sesuai dengan PSAK 107 tentang akuntansi ijarah. Untuk pencatatan pembiayaan ijarah yang direstrukturisasi, PT. Bank Syariah "X" Indonesia akan mencatat pelunasan akad yang ada dan mengganti dengan akad baru yang telah disesuaikan baik dalam jumlah angsuran maupun jadwal pembayaran yang sebelumnya telah disepakati oleh nasabah dan PT. Bank Syariah "X” Indonesia.

Adapun saran yang dapat diberikan adalah sebagai berikut. Pertama, PT. Bank Syariah "X" Indonesia hendaknya menerapkan prinsip kehati-hatian dengan lebih selektif terhadap nasabah yang mengajukan pembiayaan di PT. Bank Syariah "X" Indonesia dengan cara melakukan studi kelayakan usaha secara objektif dan menyeluruh sebelum menyetujui untuk memberikan pembiayaan. Kedua, PT. Bank Syariah "X” Indonesia hendaknya melakukan pengikatan jaminan dari nasabah secara sempurna dan melakukan pemeriksaan terhadap jaminan nasabah dan usahanya untuk antisipasi apabila kemudian hari nasabah tersebut mengalami kesulitan dalam melunasi kewajibannya. Ketiga, kepada peneliti selanjutnya agar melakukan penelitian mengenai pembiayaan bermasalah lainnya, seperti pada pembiayaan mudharabah, murabahah, musyarakah, istishna dan qardh.

\section{DAFTAR PUSTAKA}

Dewi, I. (2009). Analisis Perlakuan Akuntansi Ijarah Dan Ijarah Muntahiyah Bit Tamlik Pada PT. Bank Muamalat, Tbk Berdasarkan PSAK No. 107. Jakarta: STEKPI.

Haris, H. (2007). Pembiayaan Kepemilikan Rumah (Sebuah Inovasi Pembiayaan Perbankan Syari’ah). La_Riba Jurnal Ekonomi Islam.

Hijrianto, D. (2010). Pelaksanaan Akad Pembiayaan Ijarah Muntahiyah Bittamlik Pada Bank Muamalat Indonesia Cabang Mataram. Semarang: Universitas Diponegoro.

Peraturan Bank Indonesia Nomor 13/13/PBI/2011 Tentang Penilaian Kualitas Aktiva bagi Bank Umum Syariah dan Unit Usaha Syariah

Peraturan Bank Indonesia Nomor 8/21/PBI/2006 Tentang Penilaian Kualitas Aktiva Bank Umum Yang Melaksanakan Kegiatan Usaha Berdasarkan Prinsip Syariah

Pernyataan Standar Akuntansi Keuangan 107: Akuntansi Ijarah 2009, IAI Press

Suhardjono. (2003). Manajemen Perkreditan Usaha Kecil dan Menengah. Yogyakarta: UPP AMP YKPN.

UU no.10/1998 tentang perbankan dan undang-undang no. 21 tahun 2008 tentang perbankan syariah

Yusuf, M., dan Wiroso. (2011). Bisnis Syariah, Edisi 2. Jakarta: Mitra Wacana Media. 